\title{
Adaptations of bacteria to marine subsurface waters studied by temperature response
}

\author{
Jed A. Fuhrman* and Farooq Azam
}

Institute of Marine Resources, A-018 Scripps Institution of Oceanography, University of California, San Diego, La Jolla, California 92093, USA

\begin{abstract}
The principal objective of this study was to determine if bacterial activities in marine subsurface waters (below the surface layer where primary productivity occurs) are dominated by a locally-adapted microbial flora or by bacteria which are better adapted to warmer surface-layer conditions. By measuring size fractionation and temperature response of leucine uptake in both surface layer and deeper samples, we concluded that while it is possible to find bacteria in the deeper water - presumably attached to sinking particles - with temperature responses similar to bacteria from the surface layer, they are responsible for only a small fraction of the total activity. Furthermore, the results support the conclusion that the turnover of dissolved organic matter in the subsurface layer is dominated by bacteria which are adapted somewhat to local temperature conditions.
\end{abstract}

While the importance of bacterioplankton in the utilization and decomposition of dissolved organic matter in marine surface waters has been amply demonstrated (e.g. Andrews and Williams, 1971; Azam and Hodson, 1977; Fuhrman and Azam, 1980, 1982), comparatively little is known about microorganisms inhabiting oceanic depths where light is insufficient for net photosynthesis. Few studies have attempted to show if particular kinds of bacterioplankton are adapted best to certain depths, although a report by Ruby et al. (1980) showed that one species of planktonic luminous bacteria tends to be most abundant at middepth. In the subsurface layer, which includes the majority of ocean waters, most food arrives as a rain of detritus' from surface waters. This study was performed to determine whether the microbial activities in subsurface waters are dominated by microorganisms which have been sinking along with this material or by indigenous microorganisms which are adapted to in situ conditions. Our measurements of the short-term temperature responses of thymidine and leucine

- Present address: Marine Sciences Research Center, State University of New York, Stony Brook, New York 11794, USA uptake support the conclusion that microbial activity in both the surface and subsurface layers is controlled by locally-adapted free-living assemblages.

For this study we sought a feature which could serve as a basis for distinction between bacteria adapted to conditions at different depths. We considered that in our study area, the Southern California Bight, the temperature optima for metabolism might be sufficiently different between bacteria derived from warm surface waters and those inhabiting cooler, deeper waters. We assayed the metabolic activity of bacteria sampled from both the near-surface and subsurface (100 to $200 \mathrm{~m}$ ) zones by measuring the rates of uptake of tritiated thymidine or leucine over a 0 to $32{ }^{\circ} \mathrm{C}$ temperature range. We chose not to study deeper subsurface samples (e.g. $1000 \mathrm{~m}$ ) because shallower samples, due to their proximity to warmer surface waters, were deemed most likely to contain some bacteria recently derived from the surface. Deeper waters would contain overlapping populations of bacteria derived from all strata above the depth of sampling, and hence might yield more complex temperature responses.

Work was done on 3 cruises in Southern California coastal waters. Sample locations, depths, and light regimes are given in Table 1 . Water was sampled in clean 51 Niskin bottles at depths indicated in Table 1. Replicate $50 \mathrm{ml}$ subsamples were equilibrated at the incubation temperature for ca. $30 \mathrm{~min}$, then uptake of tritiated leucine (final concentration 4 to $10 \mathrm{nM}$; Azam and Holm-Hansen, 1973) or uptake and TCA-insoluble incorporation of tritiated thymidine (final concentration $5 \mathrm{nM}$; Fuhrman et al., 1980) was measured from 2.5 to $5 \mathrm{~h}$ incubations. Previous experiments with similar water samples showed uptake is fairly linear within this time frame (Azam and Holm-Hansen, 1973 and unpubl.). The 'total microbial assemblage' was collected on $0.45 \mu \mathrm{m}$ pore size Millipore filters and the $>1$ 
Table 1. Sampling locations, depths and light levels

\begin{tabular}{|c|c|c|c|c|}
\hline Cruise ${ }^{*}$ & Station \# & $\begin{array}{l}\text { Station } \\
\text { location }\end{array}$ & Depth (m) & $\begin{array}{l}\text { Photic zone } \\
\text { depth }(\mathrm{m})\end{array}$ \\
\hline 1 & I & $34^{\circ} 5^{\prime} \mathrm{N}, 125^{\circ} 5^{\prime} \mathrm{W}$ & 5 & ND $\cdots$ \\
\hline 1 & II & $32^{\circ} 34^{\prime} \mathrm{N}, 118^{\circ} 11^{\prime} \mathrm{W}$ & 30 & $\approx 60$ \\
\hline 1 & III & $32^{\circ} 57^{\prime} \mathrm{N}, 117^{\circ} 20^{\prime} \mathrm{W}$ & 45 & ND $\cdots$ \\
\hline 2 & IV & $32^{\circ} 57^{\prime} \mathrm{N}, 117^{\circ} 19^{\prime} \mathrm{W}$ & 1 & 30 \\
\hline 2 & IV & $32^{\circ} 57^{\prime} \mathrm{N}, 117^{\circ} 19^{\prime} \mathrm{W}$ & 98 & 30 \\
\hline 2 & v & $33^{\circ} 45^{\prime} \mathrm{N}, 118^{\circ} 47^{\prime} \mathrm{W}$ & 200 & 49 \\
\hline 3 & IVa & $32^{\circ} 57^{\prime} \mathrm{N}, 117^{\circ} 19^{\prime} \mathrm{W}$ & 2 & 31 \\
\hline 3 & IVa & $32^{\circ} 57^{\prime} \mathrm{N}, 117^{\circ} 19^{\prime} \mathrm{W}$ & 100 & 31 \\
\hline 3 & VT & $33^{\circ} 7^{\prime} \mathrm{N}, 118^{\circ} 32^{\prime} \mathrm{W}$ & 7 & 30 \\
\hline 3 & VI & $33^{\circ} 7^{\prime} \mathrm{N}, 118^{\circ} 32^{\prime} \mathrm{W}$ & 99 & 30 \\
\hline 3 & VII & $33^{\circ} 50^{\prime} \mathrm{N}, 118^{\circ} 35^{\prime} \mathrm{W}$ & 10 & 42 \\
\hline 3 & VII & $33^{\circ} 50^{\prime} \mathrm{N}, 118^{\circ} 35^{\prime} \mathrm{W}$ & 100 & 42 \\
\hline
\end{tabular}

$\mu \mathrm{m}$ size fraction was collected on $1.0 \mu \mathrm{m}$ pore size Nuclepore filters (Azam and Hodson, 1977). Within a given experiment, all subsamples were treated identically except for incubation temperature. Temperaturedependent blank values, from subsamples poisoned with $0.7 \mu \mathrm{M} \mathrm{HgCl}_{2}$ or $0.1 \%$ formalin, were subtracted. Water temperature was measured with reversing thermometers on the Niskin bottles or a conductivity-temperature-depth probe.

Thymidine uptake and incorporation in surface layer samples were highly temperature dependent with pronounced temperature optima a few degrees centigrade above the ambient water temperature, and activity dropped sharply above the optima (Fig. 1A). The temperature optimum for leucine uptake by the total microbial assemblage in 1 surface layer sample was also apparently close to ambient temperature, while in the 3 other samples, the optima were at or above the highest temperatures tested (Fig. 1B). Note that the temperature optima for leucine uptake by the total microbial assemblages in the relatively cool subsurface samples were always lower than those for the warmer overlying surface layer samples from the same stations (Fig. 1B). Thus, as we suspected, the total assemblages seemed somewhat adapted to ambient temperature conditions.

In an attempt to measure the activity of bacteria in the subsurface waters which might have recently derived from surface waters, we decided to examine the leucine uptake by the $>1 \mu \mathrm{m}$ size fraction. Leucine uptake was used as the measure of activity because it is extremely sensitive. Size fractionation was used because the most likely route by which surface layer bacteria can be transported to deeper waters is by 'riding' sinking particles, so the $>1 \mu \mathrm{m}$ size fraction of a given subsurface sample would be a good place to look for such bacteria. The separation of sinking 'immigrant' vs. nonsinking 'native' bacteria by size fractionation is probably helped by the fact that the free bacteria (mostly <1 $\mu \mathrm{m}$; Azam and Hodson, 1977; Fuhrman, 1981) sink so slowly that they generally stay at the same depth, while bacteria attached to bits of detritus can sink many meters per day.

Size fractionation results can be interpreted in a few ways. While it is probably true that the leucine uptake activity in the $>1 \mu \mathrm{m}$ size fraction is partially due to uptake by eukaryotes such as algae (Azam and Hodson, 1977), recent autoradiographic evidence from Southern California coastal waters suggests that algal amino acid uptake is generally low (Fuhrman and Azam, 1982). Thus it would appear that the small numbers of bacteria attached to particles (usually a few percent of the total; Hodson et al., 1981) are capable of the small percentage of uptake activity observed in the $>1 \mu \mathrm{m}$ size fractions.

The temperature response data for the $>1 \mu \mathrm{m}$ size fractions (Fig. 1B) show that in the surface layer, the $>1$ $\mu \mathrm{m}$ particles had the same temperature responses as the total assemblages. However, in the subsurface waters, the temperature responses consistently showed that the optimum temperatures for the $>1 \mu \mathrm{m}$ fractions were higher than those for the total assemblages (lower graphs in Fig. 1B). Significantly, the temperature responses of the $>1 \mu \mathrm{m}$ subsurface samples usually coincided with those of the overlying surface layer, which is the source of sinking particles (compare dashed lines in upper and lower graphs, Fig. 1B).

It is important to note that in both surface and sub- 


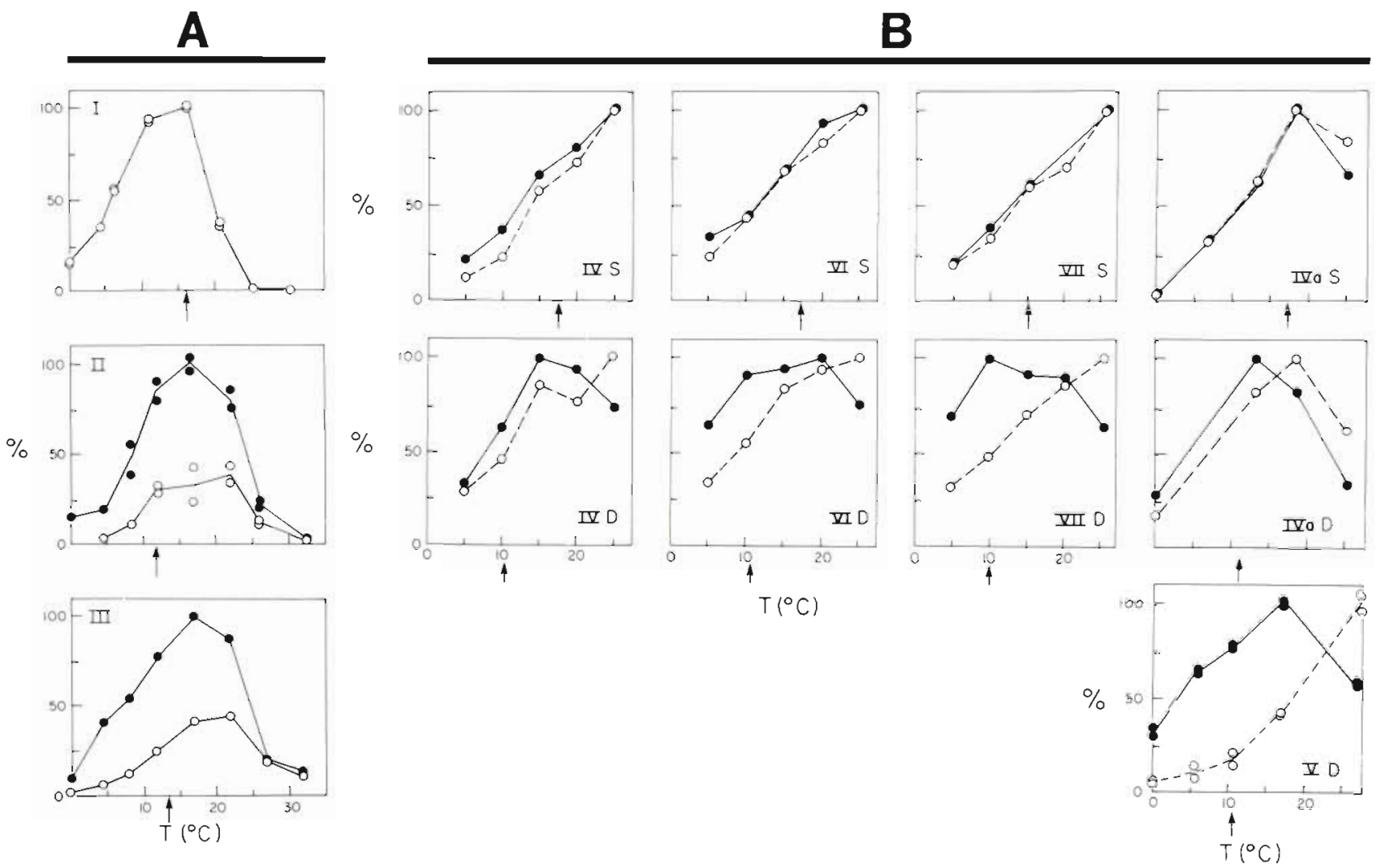

Fig. 1. Temperature responses (A) of thymidine uptake $(\bullet)$ and TCA-insoluble incorporation (o); in each case $100 \%$ is the highest uptake rate for that water sample (highest incorporation rate in I). (B) of leucine uptake for the total assemblage ( $\bullet$ ) and the $>1 \mu \mathrm{m}$ size fraction (o). Values plotted as percentages of highest uptake rate for that fraction in each water sample. S: surface layer; D: deeper, subsurface waters. Arrows: ambient water temperature; Roman numerals: sample location (Table 1)

surface waters, the $>1 \mu \mathrm{m}$ fraction contributed only a small amount to the total activity (Table 2). In surface waters, the $>1 \mu \mathrm{m}$ fraction averaged $4.9 \%$ of the total leucine uptake at ambient temperature, and in the subsurface waters the contribution averaged $4.1 \%$. These percentages are similar to those found by Azam and Hodson (1977) for D-glucose uptake.

Temperature response data from the size-fraction-

Table 2. Total and $>1 \mu \mathrm{m}$ uptake rates at ambient temperatures

\begin{tabular}{|c|c|c|c|c|c|}
\hline Station & $\begin{array}{l}\text { Depth } \\
\text { (m) }\end{array}$ & Substrate ${ }^{\circ}$ & $\begin{array}{l}\text { Concentration } \\
\text { added (nM) }\end{array}$ & $\begin{array}{c}\text { Total uptake } \\
(\% / \mathrm{h})\end{array}$ & $\begin{array}{c}\text { Uptake }>1 \mu \mathrm{m} \\
(\% \text { of total })\end{array}$ \\
\hline I & 5 & $\mathrm{TdR}$ & 5 & $0.12^{+}$ & ND \\
\hline II & 30 & TdR & 5 & 0.24 & ND \\
\hline III & 45 & $\mathrm{TdR}$ & 5 & 0.24 & ND \\
\hline IV & 1 & leu & 4 & 5.1 & 3.3 \\
\hline IV & 98 & leu & 4 & 1.1 & 4.2 \\
\hline IVa & 2 & leu & 4 & 4.5 & 3.4 \\
\hline IVa & 100 & leu & 4 & 1.1 & 2.9 \\
\hline V & 200 & leu & 8 & 0.14 & 2.6 \\
\hline VI & 7 & leu & 10 & 1.5 & 4.2 \\
\hline VI & 99 & leu & 10 & 0.18 & 4.9 \\
\hline VII & 10 & leu & 10 & 2.7 & 8.8 \\
\hline VII & 100 & leu & 10 & 0.67 & 6.1 \\
\hline \multicolumn{6}{|c|}{$\begin{array}{l}\text { TdR, thymidine; leu, leucine } \\
+ \text { Cold-TCA insoluble incorporation rate (total uptake not measured) } \\
\text { ND Not determined }\end{array}$} \\
\hline
\end{tabular}


ated samples support the conclusion that on average the attached bacteria in the subsurface waters (to at least $200 \mathrm{~m}$ ) have not been there long enough to adapt to or be selected for local temperature conditions, while the free-living bacteria are more adapted. The fact that the $>1 \mu \mathrm{m}$ fractions had only a few percent of the total activity in both surface and subsurface waters further supports the notion that free-living microorgansims are responsible for most of the turnover of dissolved organic compounds in pelagic marine ecosystems (Azam and Hodson, 1977).

This is not to say that microbial activity in the vicinity of particles is not enhanced. In fact, the techniques used here to sample water and measure microbial activity may bias the results somewhat against microbial activity associated with large particles; Niskin bottles may not effectively collect rare and rapidly sinking particles (Gardner, 1977) and 'marine snow' (Trent et al., 1978) and the microbes associated with these particles may rely more on rich microenvironments than on dilute dissolved organics. However, recent studies have shown that Niskin bottles can be as effective as sediment traps for the collection of bacteria attached to particles (Ducklow et al., 1982). Even if the results only applied to the turnover of dissolved organics, it is significant to note that in depths to at least $200 \mathrm{~m}$, this process is dominated by what appears to be a well-adapted, free-living, indigenous microbial community. Thus it might be inferred that the decomposition of dissolved organic matter in these waters is not dependent upon the bacteria arriving from surface waters.

Acknowledgements. We thank N. Cooper for technical assistance and Dr. C. Lorenzen for donating time and space on the R/V 'Thomas G. Thompson'. Drs. M. Mullin, K. Nealson, J. Gieskes, and S. Horrigan, as well as D. Comeau-Fuhrman reviewed the manuscript. This work was funded by National Science Foundation grant OCE79-26458, and Department of Energy grant DE-AM03-79SF00010.

\section{LITERATURE CITED}

Andrews, P., Williams, P. J. IeB (1971), Heterotrophic utilization of dissolved organic compounds in the sea. III. Measurement of the oxidation rates and concentrations of glucose and amino acids in sea water J. mar. biol. Ass. U. K. 51: 111-125

Azam, F., Hodson, R. E. (1977). Size distribution and activity of marine heterotrophs. Limnol. Oceanogr. 22: 492-501

Azam, F., Holm-Hansen, O. (1973). Use of tritiated substrates in the study of heterotrophy in seawater. Mar. Biol. 23: 191-196

Ducklow, H. W., Kirchman, D. L., Rowe, G. T. (1982). Production and vertical flux of attached bacteria in the Hudson River plume of the New York Bight as studied with floating sediment traps. Appl. environ. Microbiol. 43: 769-776.

Fuhrman, J. A. (1981). Influence of method on the apparent size distribution of bacterioplankton cells: epifluorescence microscopy compared to scanning electron microscopy. Mar. Ecol. Prog. Ser. 5: 103-106

Fuhrman, J. A., Ammerman, J. W., Azam, F. (1980). Bacterioplankton in the coastal euphotic zone: distribution, activity, and possible relationships with phytoplankton. Mar. Biol. 60: 201-207

Fuhrman, J. A., Azam, F. (1980). Bacterioplankton secondary production estimates for coastal waters of British Columbia, Antarctica, and California. Appl. environ. Microbiol. 39: 1085-1095

Fuhman, J. A., Azam, F. (1982). Thymidine incorporation as a measure of heterotrophic bacterioplankton production in marine surface water: evaluation and field results. Mar. Biol. 66: 109-120

Gardner, W. D. (1977). Incomplete extraction of rapidly settling particles from water samplers. Limnol. Oceanogr. 22 $764-768$

Hodson, R. E., Maccubbin, A. E., Pomeroy, L. R. (1981) Dissolved adenosine triphosphate and its utilization by free-living and attached bacterioplankton. Mar. Biol. 64: $43-51$

Ruby, E. G., Greenberg, E. P., Hastings, J. W. (1980). Planktonic marine luminous bacteria: species distribution in the water column. Appl. environ. Mircobiol. 39: 302-306

Trent, J. D., Shanks, A. L., Silver, M. W. (1978). In situ and laboratory measurements on macroscopic aggregates in Monterey Bay, California. Limnol. Oceanogr. 23: 626-635

Accepted for printing on May 5, 1983 